\title{
Intimate Partner Violence during the COVID-19 Pandemic: An Impending Public Health Crisis in Africa
}

Brendah Nakyazze

Department of Developmental Psychology, Åbo Akademi University, Finland

\section{ABSTRACT}

With COVID-19 officially declared a global pandemic and changing the social, economic, and political dynamics worldwide, countries are taking different measures to tackle its spread to save lives, which now comes as the number one priority. Different countries are in lockdown with travel restricted and quarantine, selfisolation, and social distancing measures in place. Other than key workers who are allowed to travel for work, people are stuck at home for extended periods of time with access to only their immediate family. Much as these measures have been beneficial in flattening the curve and therefore proved effective in tackling the spread of COVID-19, however, they have, been associated with an increase in the reported cases of Intimate Partner Violence (IPV) across the world, and this poses another public health challenge. With African countries already registering some of the highest global prevalence rates of IPV, it is essential to explore the impact of the COVID-19 measures will have on IPV in Africa.

Keywords: COVID-19 pandemic, gender-based violence, intimate partner violence, quarantine
Please cite this article as: Nakyazze B. Intimate Partner Violence during the COVID-19 Pandemic: An Impending Public Health Crisis in Africa. Anatol J Family Med 2020;3(2):92-95.

Address for correspondence: Dr. Brendah Nakyazze.

Department of Developmental Psychology, Åbo Akademi University, Finland

Phone: +447939047478

E-mail:

brendah.nakyazze@abo.fi

Received Date: 14.05.2020

Accepted Date: 22.06.2020

Published online: 21.08 .2020

(C) Copyright 2020 by Anatolian Journal of Family Medicine Available online at www.anatoljfm.org

OPEN ACCESS

\section{INTRODUCTION}

Intimate Partner Violence (IPV) transcends racial, social, and religious lines. This has manifested during the COVID-19 pandemic, where different countries, on different continents, have experienced a surge in the cases of IPV ${ }^{[1]}$ Globally, some of the highest prevalence rates of male perpetrated IPV are found in cultures with patriarchal beliefs and unequal gender roles, with women only reduced to subordinate roles..$^{[2]}$ Gender discrimination in such cultures starts at a very early age, and young girls are married off against their will, as is the case in many African countries. ${ }^{[3,4]}$ Additionally, a significant proportion of both men and women endorse IPV in such cultures, and this reduces the chance for a systemic social response. Although such attitudes and beliefs are not the only vindications for IPV, they, however, sustain communities' tolerance to it. ${ }^{[2]}$ Physical, sexual and psychological IPV tend to overlap within abusive relationships and this amplifies the burden placed on victimised partners. ${ }^{[5]}$

As nations scuffle to cope with the spread of the COVID-19 virus, another public health crisis is looming, as soaring evidence indicates that the conditions arise from the COVID-19 pandemic have led to a perfect environment for IPV to thrive. ${ }^{[6,7]}$ Research conducted on the impacts of pandemics on domestic violence indicates that there is always an increase in male perpetrated IPV during emergencies, such as epidemics and pandemics. ${ }^{[8]}$ The United Nations Population Fund has predicted an alarming rate of 15 million more cases of gender-based violence globally every three months lock-down rules and restrictions continue to be observed ${ }^{[2]}$ Organisations, such as the United Nations, have appealed to governments to act fast and to take all the necessary measures to curb the global surge in IPV during the COVID-19 pandemic. ${ }^{\left[{ }^{9]}\right.}$ 


\section{IPV during Quarantine}

With quarantine and social distancing measures already in place in many countries throughout the world, many people have been confined to their homes for several weeks now with reduced freedom of movement. For those in volatile relationships, staying at home for such extended periods of time makes the home not a safe haven as such. ${ }^{[10]}$ During isolation, there is increased day-to-day exposure of victims to their violent partners hence an increased risk of IPV. ${ }^{[5]}$ Spending extended time in close proximity with a spouse under circumstances of duress is known to increase IPV because even very minor issues can become a stressor or a trigger. ${ }^{[11]}$ Additionally, the unprecedented stress and anxiety triggered by the COVID-19 pandemic and the uncertainty about when it is all going to end, coupled with the economic uncertainty, have all escalated the rate of IPV in relationships with pre-existing IPV tendencies, as well as a risk factor for IPV for couples that were not in a violent relationship before. ${ }^{[12]}$

Isolation and social distancing measures have also shattered most of the support network for IPV victims making it far more challenging to get help, escape or find safety. ${ }^{[13]}$ Before the pandemic, a victim could easily escape a violent situation by seeking refuge at a neighbour's, family member's or friend's home or by reporting the incident to the authorities. However, for many victims, these safety options are certainly not available right now thereby leaving the victims trapped in an accelerating cycle of angst. ${ }^{[14]}$ There has also been reduced access to vital resources for victims of IPV, such as reproductive health and sexual services for victimised women in Africa. However, as is with the response to the COVID-19 virus itself, time is of the essence and delays in helping victims of IPV may unfortunately lead to irreversible harm being inflicted on the victims. ${ }^{[7]}$

Abusers are also using the restrictions imposed due to the pandemic to exert excessive controlling behaviour on their partners, and the lockdown measures grant them greater freedom to exploit their victims without consequence or scrutiny. Perpetrators are isolating the victims from all informal and formal support systems, such as family, friends, employment and even access to services or help when needed as a control tactic. The victims are under constant surveillance and are told how to behave, what to do and when to do it and this goes as far as having to seek permission to have telephone conversations with family and friends. ${ }^{[15]}$ Controlling behaviour may be a coping mechanism for some perpetrators who feel a loss of control because the conditions arise from the COVID-19 pandemic have left many people feeling helpless. ${ }^{[1]}$

\section{Lenses on Africa}

When the initial reports of an increase in IPV during this pandemic started pouring in, experts were worried that the numbers would only drastically increase. ${ }^{[5]}$ With the number of reported cases of IPV soaring and domestic violence hotlines busier than usual in countries, such as China, Spain, Italy, Britain, France and Turkey, where quarantine and social distancing regulations have been in effect for weeks to months now, Africa is catching up and at an alarming rate. ${ }^{[16]}$ While the official statistics put out by representatives in some Africa countries point to a rise in domestic violence, these data are seldom a true reflection of the severity of the problem. ${ }^{[17]}$

Although evidence on IPV in Africa during COVID- 19 pandemic is extremely rare, sketchy and not a true representation of the scale of the problem, South Africa is leading the way among African countries in the fight against IPV during this pandemic and using different platforms, such as the media to communicate the scale of the problem. Through an official statement made by the South African Police minister, 87.000 complaints of gender-based violence were reported in just the first week of imposing lockdown measures in South Africa. ${ }^{[18]}$ South Africa's genderbased violence head centre in Tshwane is being stretched beyond capacity as they have reported to now receiving approximately 500 to 1000 calls daily from women, and unfortunately, children as well. There are not enough social workers and resources to handle such a magnitude of complaints; therefore, the response and follow-up have not been effective. ${ }^{[19]}$ In East Africa, Kenya has also reported that the measures introduced to counter the spread of the COVID-19 virus have increased the risk of gender-based violence with more vulnerable groups, such as women and children at risk of physical and sexual violence by relatives and intimate partners. The deputy police spokesperson in Uganda, through a media press conference, said 328 IPV related cases were reported to the police during the first two weeks lockdown measures were implemented in Uganda. ${ }^{[20]}$ West Africa has also seen a surge in IPV as is the case in the Lagos state in Nigeria where cases of IPV have doubled since lockdown was enforced due to the long hours couples in violent relationships spend together. The domestic violence response team in Lagos had to increase the number of help lines to manage the growing number of victims in need of their services. ${ }^{[17]}$

Most cases of IPV in Africa are hardly disclosed to friends and family or even reported to the authorities. Women choose to stay silent in abusive relations due to several reasons, such as having a strong emotional attachment to 
their partners, fear of being judged, the stigma attached to IPV, fear of embarrassing themselves and the whole family unit, the repercussions they may face, such as loss of economic support if the perpetrator is the breadwinner, as well as the fear that if they choose to separate from their abusers, it may increase harm to their personal physical safety and that of their children. ${ }^{[13]}$ Many victims of IPV do not even recognise it as abuse but rather a mere misunderstanding with a partner/spouse even when violence is involved. Within many African social norms and cultures, the sanctity of a family unit and home should always be protected and what goes on between intimate partners should only be discussed "behind closed doors" between the affected parties, and a divorce is never an option..$^{[21]}$ The quarantine and social distancing restrictions further complicate the reporting process because the institutions that normally protect victims of domestic violence, such as the police, social services, help lines and Non-Government Organisations, are all overstretched or closed during the pandemic. In Africa, such institutions are usually underfunded and weak, to begin with, and are evidently now straining to effectively respond to the amplified demand of their services during the current pandemic. ${ }^{[22]}$ With most African countries considered Third World, governments in Africa do not have the resources to fight a public health crisis in the middle of the COVID-19 pandemic. Most of the focus and resources (which are already very limited in most African countries) are directed to-wards combating the spread of the COVID-19 pandemic and IPV is not a priority, therefore, deemed non-urgent during such times.

\section{CONCLUSION}

While the severity and depth of the COVID-19 pandemic are yet to be felt, it is already evident that the economic shock will be felt in many households throughout the world, with more devastating consequences suffered from populations with pre-existing economic vulnerability as is the case in many African countries. ${ }^{[13]}$ Research suggests that in the wake of major personal crises and financial set-backs, such as unemployment or reduced level of income earned, the rate of homicide by intimate partners tends to skyrocket. ${ }^{[1]}$ Eventually and possibly very soon, the lockdown measures are going to be lifted in most countries. However, given the way COVID-19 is wrecking economies in almost all parts of the world, the danger of IPV and its escalation into a lifethreatening situations will likely to intensify. Further still, IPV is associated with a myriad of physical, economic, or psychological consequences that could last a lifetime for the victims. Way after the COVID-19 pandemic, some of these consequences of IPV will still be felt by the victims. ${ }^{[14]}$

\section{Disclosures}

Peer-review: Externally peer-reviewed.

Conflict of Interest: None declared.

\section{REFERENCES}

1. Peterman A, Potts A, O'Donnell M, Thompson K, Shah N, Oertelt-Prigione $S$, et al. Pandem-ics and violence against women and children. Washington, DC: Center for Global Development Working Paper 528 April 2020. Available at: https:// www.cgdev.org/sites/default/files/pandemics-and-vawg.pdf. Accessed Jul 9, 2020.

2. The UN Population Fund (UNFPA). Impact of the COVID-19 pandemic on family planning and ending gender-based violence, female genital mutilation and child marriage. Available at: https://www.unfpa.org/resources/impact-covid-19-pandemic-family-planning-and-ending-gender-based-violencefemale-genital. Accessed Jul 9, 2020.

3. Gibbs A, Dunkle K, Ramsoomar L, Willan S, Jama Shai N, Chatterji $\mathrm{S}$, et al. New learnings on drivers of men's physical and/ or sexual violence against their female partners, and women's experiences of this, and the implications for prevention interventions. Glob Health Action 2020;13(1):1739845.

4. The Guardian. Calamitous: domestic violence set to soar by 20\% during global lockdown. Available at: https://www.theguardian.com/global development/2020/apr/28/calamitousdomestic-violence-set-to-soar-by-20-during-global-lockdown-coronavirus. Accessed Jul 9, 2020.

5. Bradbury-Jones $C$, Isham L. The pandemic paradox: The consequences of COVID-19 on domestic violence. J Clin Nurs 2020;29(13-14):2047-9.

6. New Zealand Family Violence Clearinghouse (NZFVC). Preventing and Responding to Fami-ly, Whānau and Sexual Violence during COVID-19. Available at:https://nzfvc.org.nz/COVID-19/preventing-responding-violence-COVID-19. Accessed Jul 9, 2020.

7. World Health Organisation. COVID-19 and violence against women. Available at: https://apps.who.int/iris/bitstream/handle/10665/331699/WHO-SRH-20.04-eng.pdf. Accessed Jul 9, 2020.

8. Fraser E. Impact of COVID-19 pandemic on violence against women and girls. London, UK: VAWG Helpdesk Research Report No. 284. Available at: https://cieg.unam.mx/covid-genero/pdf/reflexiones/academia/impact-of-covid-pandemic.pdf. Accessed Jul 9, 2020.

9. UN News. UN chief calls for domestic violence "ceasefire" amid "horrifying global surge". Available at: https://news.un.org/ en/story/2020/04/1061052. Accessed Jul 9, 2020.

10. van Gelder N, Peterman A, Potts A, O'Donnell M, Thompson K, Shah N, et al. COVID-19: Reducing the risk of infection might increase the risk of intimate partner violence. Version 2. EClinicalMedicine 2020;21:100348. 
11. The Guardian. Lockdowns around the world bring rise in domestic violence.Available at: https://www.theguardian. com/society/2020/mar/28/lockdowns-world-rise-domesticviolence?CMP=Share_iOSApp_Other. Accessed Jul 9, 2020.

12. Campbell AM. An increasing risk of family violence during the Covid-19 pandemic: Strengthening community collaborations to save lives. Forensic Science International: Reports 2020;2:100089.

13. Flowe HD, Kanja W. How can we protect women and children at risk from violence during the COVID-19 crisis? Available at: https://www.birmingham.ac.uk/ news/thebirminghambrief/ items/2020/04/how-can-we-protect-women-and-childrenat-risk-from-violence-during-the-covid-19-crisis.aspx. Accessed Jul 9, 2020.

14. Abramson A. How COVID-19 may increase domestic violence and child abuse. American Psychology Association. Available at: https://www.apa.org/topics/covid-19/domestic-violencechild-abuse. Accessed Jul 9, 2020.

15. Taub A. A new Covid-19 crisis: Domestic abuse rises worldwide. Available at: https://www.nytimes.com/2020/04/06/ world/coronavirus-domestic-violence.html. Accessed Jul 9, 2020.

16. Ünker P, Bellut D. Domestic violence rises in Turkey during COVID-19 pandemic. Available at: https://p.dw.com/p/3aj8f. Accessed Jul 9, 2020.

17. Sahara Reporters. COVID-19 lock down: Domestic/sexual cases rise in Lagos, Government warns perpetrators. Available at: http://saharareporters.com/2020/04/20/ covid-19-lockdowndomesticsexual-violence-cases-rise-lagos-governmentwarns-perpetrators. Accessed Jul 9, 2020.

18. Masweneng K. Gender-based violence complaints hit 87,000 so far in lockdown, as cop ar-rested for allegedly raping wife. Available at: https://www.timeslive.co.za/news/southafrica/2020-04-03-gender-based-violence-complaintshit-87000-so-far-in-lockdown-as-cop-arrested-for-allegedlyraping-wife/. Accessed Jul 9, 2020.

19. Bhekisisa J. Home sweet hell: Calls for help surge from women locked down with abusers. Available at: https://www.news24. com/SouthAfrica/News/home-sweet-hell-calls-for-helpsurge-from-women-locked-down-with-abusers-20200414. Accessed Jul 9, 2020.

20. Matovu M. 328 cases of domestic violence reported during the Covid-19 lockdown so far. Available at: https://nilepost. co.ug/2020/04/17/328-cases-of-domestic-violence-reportedduring-covid-19-lockdown-so-far/. Accessed Jul 9, 2020.

21. Rajah V, Osborn M. Understanding women's resistance to intimate partner violence: A scop-ing review. Trauma, Violence, \& Abuse. Available at: https://journals.sagepub.com/doi/ abs/10.1177/1524838019897345. Accessed Jul 9, 2020.

22. Odhiambo A. Tackling Kenya's domestic violence amid COVID-19 crisis. Available at: https://www.hrw.org/ news/2020/04/08/tackling-kenyas-domestic-violence-amidcovid-19-crisis. Accessed Jul 9, 2020. 